\title{
International Association for the Study of Clays
}

\section{(AIPEA)}

\section{http://www.aipea.org}

During the 18th International Geological Congress in London in 1948 , the clay scientists present met to discuss international cooperation and exchange of information within their common field of research. It was then decided that a committee should be set up under the International Geological Congress. This was approved by the congress and the committee was named Comite International Pour L'Etude Des Argiles (CIPEA). Professor Ralph E. Grim of the University of Illinois was elected the first president of the committee and he presided until 1960. Between 1960 and 1966 the president was Professor Ivan Th. Rosenqvist of the University of Oslo. The secretaries were Dr. W. F. Bradley of the Illinois State Geological Survey (1952-1956), Dr. Simone Caillère, Muséum National d'Histoire Naturelle (1956-1960), and Dr. Poul Graff-Petersen, University of Copenhagen (1960-1966). Scientific sessions arranged by CIPEA were held during the International Geological Congresses in Algiers (1952), Mexico City (1956), and Copenhagen (1960). At the meeting in Copenhagen in 1960, members present decided that CIPEA should arrange its own conferences, and the first International Clay Conference was held in Stockholm, Sweden, in 1963, with four days of scientific sessions followed by field trips to clay localities in Sweden, Norway, and Denmark.

At the 1963 International Clay Conference, members resolved that CIPEA should cease being a committee under the International Geological Congress, that an international association should be established, and that this association should seek affiliation with the International Union of Geological Sciences. The 22nd International Geological Congress in New Delhi in 1964 agreed that the committee should no longer be under the congress. At its meeting in January, 1966, the Executive Committee of the International Union of Geological Sciences agreed to the affiliation.

During the International Clay Conference in Jerusalem, Israel, in 1966, a meeting of the General Assembly was held. At this meeting, statutes and by-laws were adopted for the Association Interna-

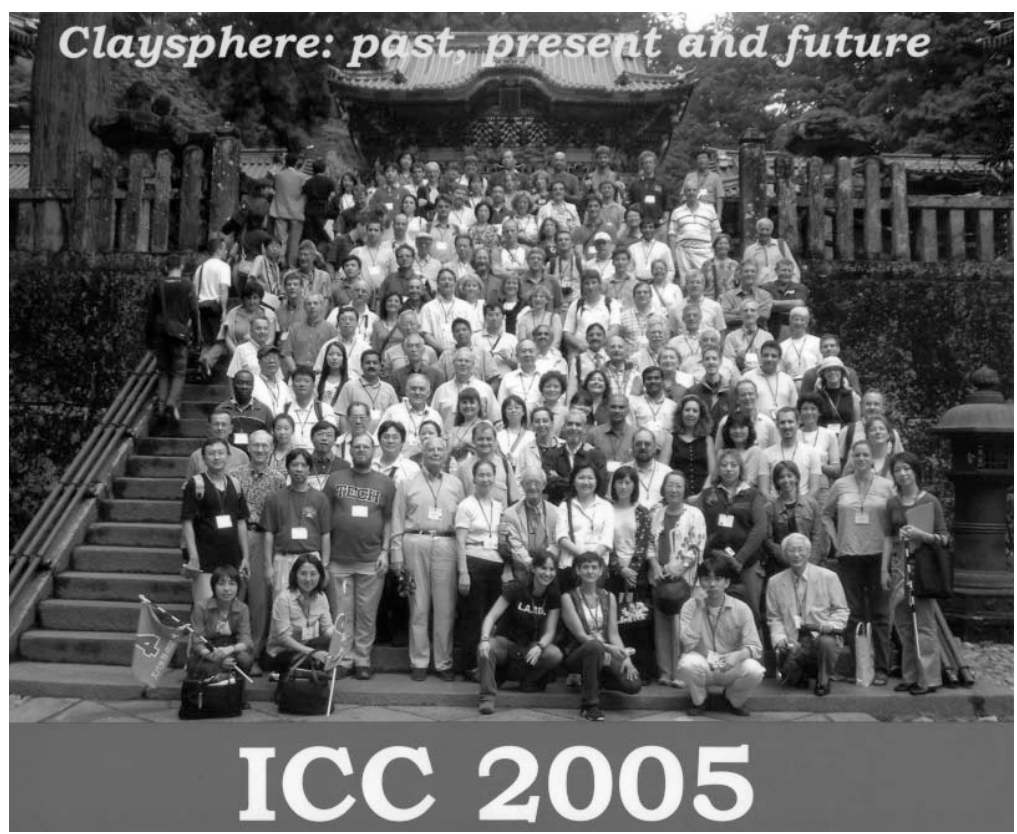

A group photo of the International Clay Conference participants at a temple during a visit to Nikko, Japan.

\section{Association internationale pour l'étude des argiles

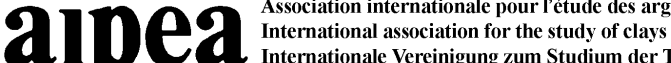 Internationale Vereinigung zum Studium der Ton}

tionale Pour L'Edute des Argiles (AIPEA), and the council was elected. Great assistance has been provided to CIPEA and AIPEA by the International Geological Congress and by the International Union of Geological Sciences since 1948.

According to the first Newsletter, the AIPEA newsletter was to be published at irregular intervals and is to be distributed to all members of the association. The Newsletter was not meant as a scientific journal but as an international link between the clay scientists of the world. The term "clay scientists" was used in its broadest sense as it covers a very large and varied group, with representatives in the cement industry, ceramics industry, civil engineering, cosmetics industry, crystallography, foundry technology, geology, geotechnology, medicine, mineralogy, paint industry, paper industry, pedology, petroleum industry, rubber industry, etc.

In its current form, AIPEA is an affiliated organization in the IUGS and it consists of the national clay societies of the world, acting as an umbrella organization to coordinate and facilitate international activities and collaborations relating to clay mineralogy (much like the International Mineralogical Association). AIPEA currently represents clay mineral societies from France, Czech Republic, Brazil, Mexico, Italy, Israel, South Korea, South Africa, Belgium, the Netherlands, Japan, Russia, Poland, Hungary, India, Spain, Romania, Australia, Columbia, Yugoslavia, Turkey, Bulgaria, the United Kingdom and Ireland, Sweden, China, Germany, Portugal, and the USA.

Broadly speaking, the aim of AIPEA has not changed since 1948 and its goal remains the worldwide promotion of international cooperation in clay research and technology. Most importantly, AIPEA accomplishes this by sponsoring the International Clay Conference (ICC) every four years. A full report of our recent annual meeting, held in August, 2005, in Tokyo, Japan, with 396 participants from 36 countries, was published in the December, 2005, issue of Elements, 1, p. 313-314.

AIPEA continues to produce an annual newsletter that contains information on the activities of our national clay society members, together with information on upcoming meetings and grant programs. We have an awards program to recognize and encourage young and more-established clay scientists. The Bradley Award is given to a young clay scientist based on a research paper, and the 2005 award winner was Dr. Javiera Cervini-Silva of the University of California at Berkeley, USA. Her Bradley Award presentation discussed the effects of iron redox cycling and the hydration properties of exchangeable cations on the Bronsted basicity of adsorbed water in ferric-ferrous 2:1 phyllosilicates. The AIPEA Medals are given to honor active clay scientists in recognition of their contributions to clay science, and the 2005 AIPEA Fellowship awards were given to Dr. José Julien Fripiat (France) and Dr. José Serratosa (Spain). AIPEA Medals for excellence in clay science, sponsored by Associación Española des Arcillas, were given to Dr. Eduardo Ruiz-Hitzky (Spain) and Dr. Stephen Guggenheim (USA).

Other activities of AIPEA include its nomenclature committee that has established consistent clay mineralogical terminology. This committee will shortly place nomenclature discussions of the past 30 years on the AIPEA web site (http://aipea.org/). The teaching committee over the next four years will investigate ways to expand clay science teaching, not only to clay scientists but particularly to those 
in the materials and chemistry fields who work with clay materials in their research.

The AIPEA Council will meet next at the Euroclay Conference in 2007 in Portugal, at which time the AIPEA Council will have formal meetings. The next International Clay Conference will be held June 20-26, 2009, and is being organized by Dr. Saverio Fiore of Italy. Organizational plans are already well underway, and a detailed scientific proposal will be put forward at the Euroclay meeting in 2007.

\section{AIPEA financial support}

AIPEA receives financial support primarily from dues of its international member societies.

\section{Relationship to IUGS}

AIPEA is an affiliated organization within the IUGS.
Treasurer

Dr. Jeanne B. Percival, Geological Survey of Canada, Canada Secretary general

Dr. J. Theo Kloprogge, Queensland University of Technology, Australia

\author{
AIPEA Council (2005-2009) \\ Dr. Peter Komadel, Slovak Academy of Sciences, Slovakia \\ Dr. Atsuyuki Inoue, Chiba University, Japan \\ Dr. N. Clauer, Centre de Geochimie de la Surface, France \\ Prof. Saverio Fiore, Consiglio Nazionale delle Ricerche, Potenza, \\ Italy \\ Dr. Celso S.F. Gomes, Universidad de Aveiro, Portugal \\ Dr. Daisy Barbosa Alves, Petroleo Brasileiro S.A., Brazil \\ Prof. Darrell G. Schulze, Purdue University, USA \\ Prof. Stephen Guggenheim, University of Illinois at Chicago, \\ USA
}

David L. Bish

Department of Geological Sciences

Indiana University

Bloomington, IN 47405

USA

Tel: $812-855-2039$

Fax: 812-855-7899

E-mail:bish@indiana.edu

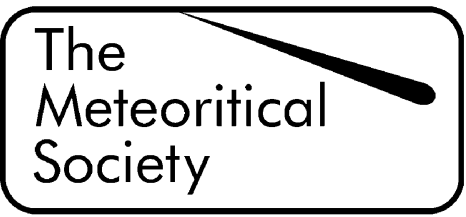

http://metsoc2007.org/

\section{0th Annual Meeting of the Meteoritical Society} Tucson, Arizona, USA August 13-17, 2007

Scientific Highlights The meeting will be held around the launch time of the Phoenix Mission to Mars. We expect to have some special sessions highlighting this and other current missions, as well as the usual topics discussed at MetSoc meetings, including:

- analytical developments

- accretion and differentiation of primitive materials

- beyond the solar system

- chondrules

- chronology of early solar system events

- differentiated meteorites

- historical aspects

- interplanetary dust particles and micrometeorites

- lunar samples and lunar meteorites

- Martian meteorites

- parent body processes

- presolar materials

- sample return missions, results, and prospects

- space missions, other
- astrobiology

- asteroids and comets

- chondrites, carbonaceous and others

- classification of meteorites

- cosmogenic nuclides

- fall and recovery of meteorites

- impact processes and structures

- isotopic anomalies

- low-temperature components

- nebular or presolar processes

- Moon, Mars, and other planets

- refractory inclusions

- shock effects

The Meeting Venue: JW Marriott Starr Pass Resort and Spa, Tucson http://marriott.com/hotels/travel/tussp-jw-marriott-starr-pass-resort-and-spa 